耳介メルケル細胞 癌

大屋 美香・五十嵐良和・長崎 正男

麻生 伸・渡辺 行雄・豊本 貴嗣*

\title{
Merkel Cell Carcinoma in the Auricle
}

\author{
Mika Ohya, Yoshikazu Igarashi, Masao Nagasaki, \\ Shin Aso, Yukio Watanabe and Takashi Toyomoto \\ (Toyama Medical and Pharmaceutical University)
}

\begin{abstract}
Merkel cell carcinoma (MCC) is a cutaneous tumor derived from neuroendocrine glands. The MCC is usually found in the head and neck area, but it is not commonly found in the auricle. We describe a 72-year-old male with Parkinsonism who complained of an elastic tumor, with a diameter of approximately $35 \mathrm{~mm}$ in the right ear lobe. There was no evidence of metastatic lesions and the patient was diagnosed to be stage I . After preoperative irradiation of $26 \mathrm{~Gy}$, the tumor decreased dramatically in size. The patient subsequently underwent extirpation surgery and postoperative irradiation of $30 \mathrm{~Gy}$. There was no local recurrence after the treatment but the patient unfortunately died of pneumonia eight months after the surgery.
\end{abstract}

Key words : Merkel cell carcinoma, preoperative irradiation, Parkinson disease

はじめに

メルケル細胞癌は皮膚由来の悪性腫瘍であり，1972年 Toker ${ }^{1}$ により初めて trabecular carcinoma of the skin の名で報告された腫瘍である。すでに世界で400例以上 の報告が見られるが本邦の報告はまだ少ない，今回，私 共は耳介に発生したメルケル細胞癌の 1 例を経験したの で報告する。

\section{症例}

症例 : 72歳, 男性.

主訴：右耳介腫瘍.

現症: 平成 6 年 6 月肺炎で他院に入院加療中, 右耳介 に点状の紅斑が出現した. 痛みもなく放置していたが, 徐々に増大したため同年 9 月 17 日当科紹介入院となった。

既往歴 : 63 歳で, 脳梗塞による右半身麻疩. 71 歳でパー キンソン病と診断され共に投薬を受けている. 平成 6 年
に肺炎，気管支拡張症に罹患している.

家族歴 : 特記すべきこと無し.

局所所見(図 1 )：右耳垂に直径 $35 \mathrm{~mm}$, ほぼ球形, 弾 性硬, 暗褐色, 表面不整, 一部出血のある腫瘤を認めた. 腫瘍の境界は明膫で周囲に皮下結節認めず, 耳下腺腫脹 やリンパ節腫脹を認めなかった.

入院時検查所見: 血液, 一般生化学検査上異常を認め ず, 腫瘍マーカーでSCC 抗原 $1.8 \mathrm{ng} / \mathrm{ml}$ (正常值 : 1.5 $\mathrm{ng} / \mathrm{ml}$ 以下)で陽性, NSE (neuro specific enolase)は $18.8 \mathrm{ng} / \mathrm{ml}$ (正常值 : $10.0 \mathrm{ng} / \mathrm{ml}$ 以下) で陽性であった. 胸部レントゲンで右上肺野の気管支拡張症を認めた. $\mathrm{CT}, \mathrm{Ga}$ シンチ, 骨シンチにて, 耳介以外の腫瘍や, リ ソパ節転移，遠隔転移を認めなかった。

生検標本病理組織所見(図 2):ヘマトキシリンエオジ ン染色で真皮層内に細胞質の少ない類円形腫瘍細胞を充 実性巣状に認め, リンパ管浸潤を認めた。核は小型で明 


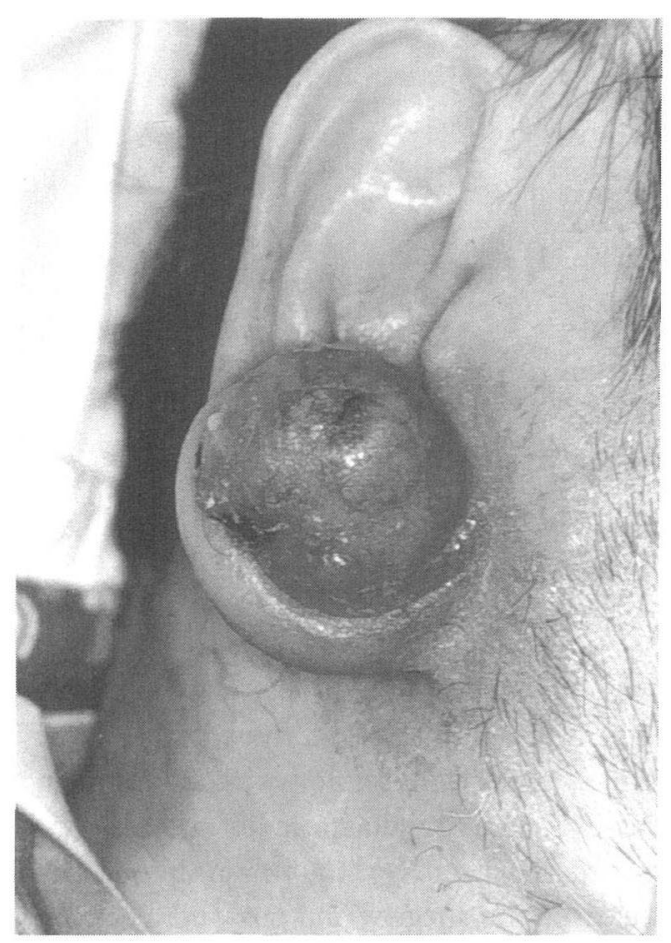

図 1 右耳介にほぼ球状の暗褐色の腫瘍が認められた。

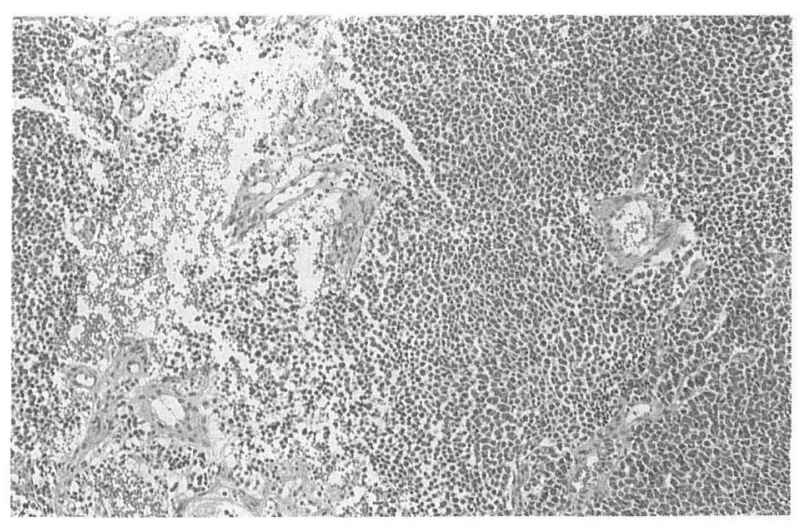

図 2 充実性の類円形腫瘍細胞が認められる $(\mathrm{HE} \times 100)$.

るく, 多くの核分裂像を認めた。腫瘍細胞は免疫組織化 学で, NSE, ケラチン陽性所見を認めた。

電䫓所見（図 3 ）：細胞膜下に一重の限界膜に包をれた 直径 $80 \sim 100 \mathrm{~nm}$ の電子密度の高いメルケル顆粒と呼ば れる暗調球形顆粒を認めた。

以上上り, 耳介以外飞腫瘍病変を認放, 組織検查の 結果より耳介原発のメルケル細胞癌と診断した。.
治療と経過：耳下腺を含光腫瘍周囲に $26 \mathrm{~Gy}$ 老術前 照射した．腫瘍は $35 \times 35 \times 35 \mathrm{~mm}$ から $25 \times 25 \times 10 \mathrm{~mm}$ に縮小し, 腫瘍の中心部に融解を認め, 表層に痂皮が形 成された。

平成 6 年 9 月 17 日, 腫瘍摘出術を施行した. 耳介下半 分は腫瘍とともに切除し, 創は一期的に縫縮した. 残存 した耳介上部にて耳公形成した(図 4). 腫瘍は弾性が あり割面は滺黄褐色で境界明瞭だった。切除標本の病理 では周囲への浸潤は認められず, 安全域が十分に確保さ れていることを確認した。術後 56 Gy まで放射線照射 を追加し，退院した。局所の再発，拉よび遠隔転移は認 められなかったが，平成 7 年 5 月腫瘍と無関係の肺炎に て死亡した.

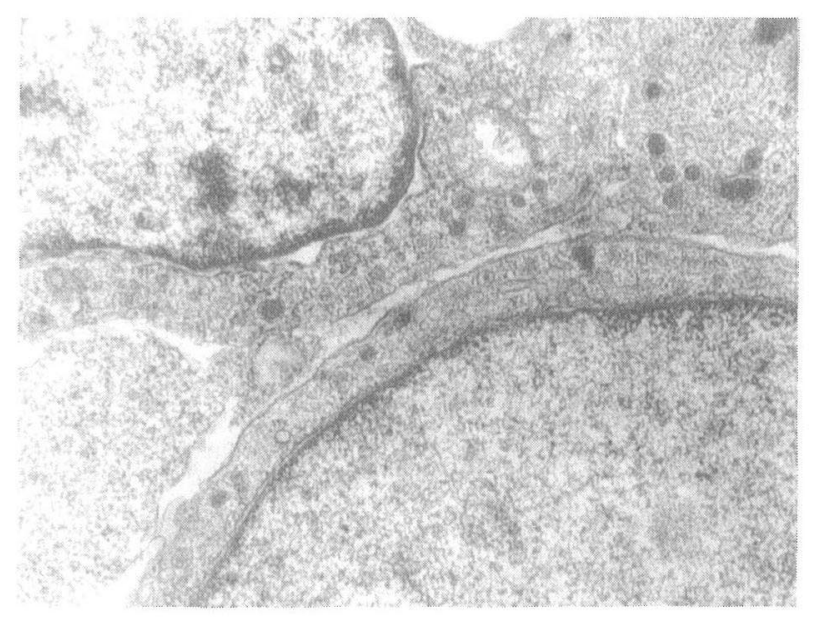

図 3 細胞質にメルケル顆粒を認める(電子顕微鏡 $\times 20,000)$.

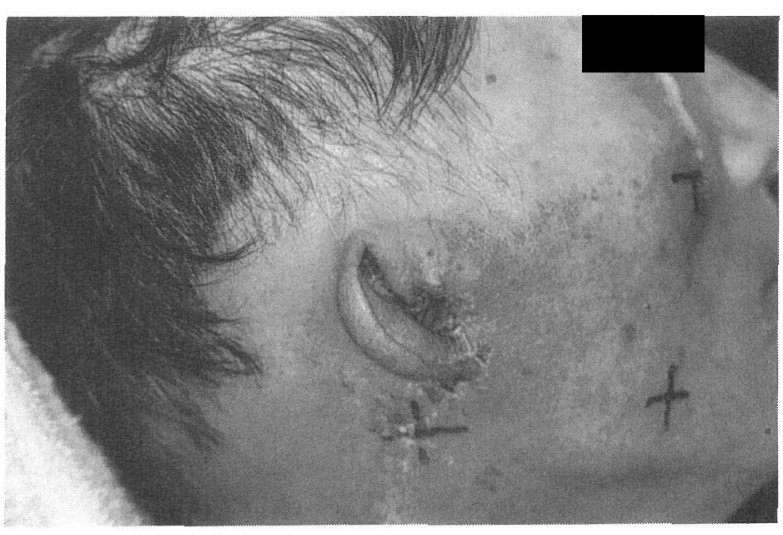

図 4 耳介形成を行った後術後照射を総量 56 Gy をで施行し た。 


\section{考察}

メルケル細胞癌は皮膚のメルケル細胞由来の皮膚原発 腫瘍で, 臨床的に無症候性の丘状の皮下結節様の腫瘍で あるとされている. メルケル細胞は皮膚の基底層や外有 毛䩗に広く分布する細胞で, 皮膚露出部に多く認められ る. 卵円形の核を持ち, 明るい細胞質の中にメルケル細 胞顆粒と呼ばれる神経内分泌顆粒と, 中間径フィラメン トと呼ばれる線維束を持つ. しかしその働きはまだ不明 な点が多い. 胎生期では末梢神経を形成するときの進展 標的としての役割を持ち, 成人期では感覚神経の中の触 圧覚の神経末端に認められることから, 触圧の受容体の ひとつと言われている2).

メルケル細胞癌は血管が豊富で暗褐色から紫褐色の色 調を示し，肉眼的に血管腫に類似している. 大ささは数 $\mathrm{mm} \sim 10$ 数 $\mathrm{cm}$ で大半は $2 \mathrm{~cm}$ 以内で発見される. 男女 比はほぼ 1：1である3). 高秢での発症が多くほとんど が60歳以上で発症する一方, 若年発症例もいくつか報告 されている．発生部位は頭頸部が55\%，四肢が40\%，体 幹が $5 \sim 10 \%$ であ. 女性の高齢者は頭頸部により好発 しやすい4). 頭頸部の内訳では煩, 上頸部, 鼻の順に頻 度が高く，耳や口腔粘膜の発症例はきわめてまれとされ ている3). 高橋 $5^{5)}$ の報告では耳介の発症例が 7 例確認 されている.

予後不良因子として挙げられるものををとめると，1） 若年発症，2)頭頸部执よび体幹発症例，3)男性，4） 局所再発やリンパ節転移の認められる例, 5 ) 何らかの 全身疾患合併例，である6). 今回の症例は他病死したが, 予後不良群と推察される.

Yiengpruksawan ら7)は腫瘍の進展度を基準にした stage 分類を試みている.すなわち局所のみ腫瘍病変の 認められるものを stage I, 所属リンパ節に転移を認め るものを stage II, 遠隔転移を認めるものを stage III としている. 本基準に従えば今回の症例は stage I に 相当する.

免疫学的特異マーカーは確定していないが, 現在 NSE が最適と言われ主に利用されている244)。ただし NSE も腫瘍自身を染色するのではなく, 神経接合部に 反応するため, 支配神経が断絶した場合は陰性となる8). そのほか, EMA (epitherial membrane antigen)や, chromograninなどの測定も試みられている2). 本症例 では，血中NSEが高値を示した。

病理学的には光顕で小型の腫瘍細胞が認められる.核
は円形で，核/細胞比が高く分裂像が多い，標本上悪性 リンパ腫や肺細胞癌に似た像を示し，鑑別が難しい。電 顕では細胞質にメルケル顆粒と呼ばれる直径 100～200 $\mathrm{nm}$ の電子密度の高い球形の顆粒が散在することが特徴 とされる. また, 細胞膜の一部の電子密度が高くなる ことで細胞間にデスモゾーム様の構造を認めることがあ り, これも特徵所見のひとつとされている2).

治療は腫瘍の拡大切除と所属リンパ節の郭清が基本的 とされている．腫瘍の大ささにかかわらず, リンパ節郭 清を併用する方が，生存率が高く再発率も低いとする報 告もある4)6). 放射線感受性が高いため, 術後に放射線 照射をすることが一般的に行われている10)11). 化学療法 は切除不能例や，遠隔転移を認めた場合併用されている. $\mathrm{CAV}$ (シクロフォスファミド，アドリアマイシン，ビ ンクリスチン)療法や P-CAV (ペプレオマイシン, シス プラチン, アドリアマイシン, ビンデシン)療法などが 良いとする報告もある12).

術前照射に関しては報告を渉編しえなかったが，本症 例では, 術前に局所沶よび周囲頸部リンパ節を含めた放 射線照射を $26 \mathrm{~Gy}$ 行ったところ, 腫瘍は明らかに縮小 し正常組織との境界が明らかとなり，切除範囲の同定が 容易となった. 本症例の経験より, メルケル細胞癌に対 する術前照射の有効性が示唆された. メルケル細胞癌の 治療として, 所属リンパ節への転移を認めない場合にも 所属リンパ節を含めた術前術後の放射線照射が有効と考 えられる。

最後に本症例は, 発症 1 年前からパーキンソン病に罹 患し治療を受けていたが, Takes ら3)の報告した頭頸部 症例 5 例中 2 例もパーキンソン病の既往があり興味が持 たれる.パーキンソン病もしくはこれに対する治療がメ ルケル細胞癌の発症の要因のひとつとなる可能性がある かもしれない，しかしこの点に関しては今後の検討が必 要と考えられる.

本論文の要旨は第 57 回耳鼻咽喉科臨床学会総会 (平成 7 年 7 月)で発表した.

\section{参考文献}

1) Toker C: Trabecular carcinoma of the skin. Arch Dermatol $105: 107 \sim 110,1972$.

2 ）落合豊子, 森嶋隆文 : メルケル細胞. 皮膚臨床 $35: 1213$ $\sim 1221,1993$. 
3 ) Takes RP, Balm AJM, Loftus BM, et al : Merkel cell carcinoma of the head and neck. Clin Otolaryngol $19: 222 \sim$ 229, 1994.

4 ) Bielamowicz S, Smith D and Abemayer E : Merkel cell carcinoma; an aggressive skin neoplasm. Laryngoscope $104: 528 \sim 532,1994$.

5 ) 高橋泰英, 宮川加奈太, 長谷哲男, 他 : 耳介に生じた Merkel Cell Carcinoma の 1 例. 臨皮 $44:$ 419 424, 1990.

6 ) Shaw JHF and Rumball E : Merkel cell tumour ; clinical behaviour and treatment. Br J Surg $78: 138 \sim 142,1991$.

7 ) Yiengpruksawan A, Coit DG, Thaler HT, et al : Merkel cell carcinoma ; prognosis and management. Arch Surg $126: 1514 \sim 1519,1991$.

8 ）鈴木啓之：メルケル細胞. 皮膚臨床 $28 ： 1089 \sim 1093,1986$.

9 ）菊池 新, 清水 宏: メルケル腫瘍. 病理と臨床 10 臨時
増刊号 : 374 375, 1992.

10) Marks ME, Kim RY and Salter MM : Radiotherapy as an adjunct in the management of Merkel cell carcinoma. Cancer $65: 60 \sim 64,1990$.

11) Wilder RB, Harari PM, Graham AR, et al : Merkel cell carcinoma; improved locoregional control with postoperative radiation therapy. Cancer $68: 1004 \sim 1008,1991$.

12）柳川 茂, 大隅正義, 米田修一, 他: 化学療法にて原発巣 の消失を見た Merkel cell carcinoma の 1 例. 皮膚臨床 32 ： $1747 \sim 1751,1990$.

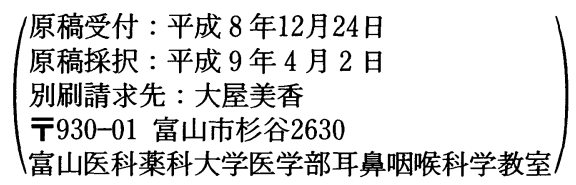

